\title{
Christianity and globalisation: An alternative ethical response
}

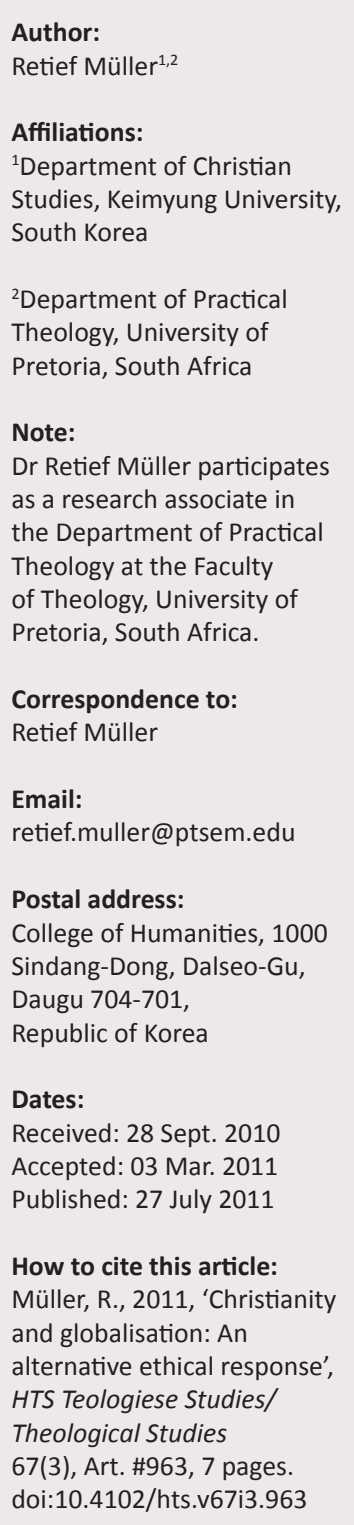

Author:

Affiliations:

${ }^{1}$ Department of Christian

Studies, Keimyung University,

Note:

the Department of Practical

Theology at the Faculty

of Theology, University of

Correspondence to:

Email:

College of Humanities, 1000

Sindang-Dong, Dalseo-Gu,

Daugu 704-701

Received: 28 Sept. 2010

Accepted: 03 Mar. 2011

blished: 27 July 2011

Müller, R., 2011, 'Christianity and globalisation: An

alternative ethical response',

Theological Studies

doi:10.4102/hts.v67i3.963

(C) 2011. The Authors.

Licensee: AOSIS

OpenJournals. This work

is licensed under the

Creative Commons

Attribution License.
This article critically evaluated the role of Christian Ethics in response to globalisation. It showed that ethical critiques of globalisation inevitably fall short when Christianity's historical contributions to processes of globalisation are neglected or de-emphasised. A Christian Ethics that attempts completely to wash its hands of and disavow globalisation is therefore indicated to be perched on a false premise. In this regard, the author specifically discussed the divergent stances of Max Stackhouse and Rebecca Todd Peters and opted for the former as the more helpful when considered from an interdisciplinary approach. In the final analysis, the author argued that the problem of globalisation might fruitfully be addressed with an ethics that is not averse to bring the various insights of missiology, church history and practical theology to the table, focusing particularly on rituals of reconciliation and forgiveness.

\section{Introduction}

\section{The problem and thesis}

This article starts with the premise that Christian Ethics as a theological field suffers from a fundamental weakness when it comes to the phenomenon known as globalisation. The article will show that, from a historical perspective, the main problem with Christian ethical critiques of globalisation is that Christianity played a major role in the creation of globalisation as we know it today. Therefore, some of the ethical critiques of globalisation may come across as self-defeating, contradictory and rooted in shaky foundations when launched from a normatively Christian stance. This article posits the thesis that this ethical dilemma could be resolved by incorporating an explicitly historical dimension into the discussion. Although history, and specifically Western Christianity's historical tendency to associate with economic and political power wielders, presents a dilemma for contemporary Christian Ethics, paradoxically, the key to unlocking the problem with a positive contribution is also connected to history and how we deal with it.

\section{Thematic background}

I started thinking about this theme when I was teaching a required course for first-year students on Christian Ethics and Globalisation at Keimyung University in South Korea. The students were mostly Korean, although there were also a few international students from places such as Russia, Japan and the Philippines. Very few students would describe themselves as Christian and even the ones that did, had only limited knowledge of the history of their religion, apart from what it says in the Bible. The rest of the students had no knowledge of Christianity, other than certain negative stereotypes fuelled by the 'health-and-wealth' evangelistic style of much of contemporary Korean Christianity.

Therefore, being charged with the near impossible task of teaching Christian Ethics and Globalisation in an environment where hardly any background existed on the subject of Christianity, I decided to tweak the course description to allow it to make better educational sense. I would give historical surveys of Christianity, on the one hand, and globalisation, on the other, and then add on some discussion about ethics at the end. Although the plan itself was not very profound, this historical focus had the positive effect of uncovering new possibilities of an interdisciplinary paradigm for teaching global Christian Ethics.

\section{Historical assesment of Christianity's role in globalisation Understanding globalisation}

Although globalisation may mean a number of different things depending on who is using it and in what context, I see it as a growing state of global interdependence and interconnectedness when considered from a purely cultural point of view. However, the more typical sense in which the term is used mainly concerns economy, as is illustrated by the definition given by 
the Merriam-Webster Dictionary (ed. Mish 2004): '... the development of an increasingly integrated global economy.' To clarify my own position within the scope of this article then, I understand Christianity's contribution to globalisation primarily in terms of culture, which, when broadly defined as encompassing all human, communal activity, would include economic activity. Therefore, although my view of globalisation is much wider than the typical view, economy, when understood as embedded in and inseparable from the wider culture, still remains pivotal to the discussion.

\section{The contemporary context}

Whilst there are times in history when theology has to be approached from the perspective of the prophet of doom, I will argue that, globally speaking, we are not currently in such a time. I am not stating this because I feel positive about the future, quite the contrary. Doom and gloom seems to be all around. Our dependency on fossil fuels has placed the global environment in a precarious position. Indeed, humanity seems trapped in a (self-)destructive cycle of having a growing need of that for which ongoing usage could ultimately make us go extinct along with many other species: oil (Chomat 2004; Lane 2008). Oil-fuelled globalisation has also managed to increase tensions between religious and ethnic groups, as well as creating conflicts where none had existed before (cf. Standlea 2006). As a species we are threatened by the potential for violence against ourselves, out of control pollution and uncontrolled population growth (Brown 2005; McGourty 2009). Even the climate seems to increasingly turn against us. Most responsible scientists and intellectuals accept the direness of the situation (cf. Oreskes 2004:1686); yet, this situation is not new by any means. The global environment has been under human pressure for a long time, but rather than easing as the nature and character of our destructive habits become better understood, that pressure seems to be increasing (cf. Chomat 2004). It is for this reason that I believe it is time for theologians, including ethicists, to discard the cloak of the prophet of doom. Theologies of hope are what we now need, precisely because the actual situation seems so gloomy.

The thirst for hope seems to grow exponentially together with an increase in understanding of the troubled context in which we find ourselves in the 21st century. This became increasingly obvious as my course on Christian Ethics and Globalisation ensued. Nevertheless, there would be no point in giving false hope, neither morally nor practically. It is necessary that the complexity regarding Christianity's contributions to globalisation be revealed in a truthful manner, albeit from an admittedly subjective stance. It was in the pursuit of this kind of truth telling, which does not neglect the sometimes hard realities, and yet without banishing those glimpses of hope that are so important for conducting Christian theology, that I adopted an explicitly historical approach in teaching the above-mentioned course. This yielded unexpected fruit, the nature of which I will describe in what follows.

\section{The historical context}

Economic global integration has been going on for a number of centuries. Globalisation in its early modern form could be understood to find its roots in the period of European exploration and colonisation of the rest of the world, from the 16th century onwards (cf. Hopkins 2003:3). Of course, the modern missionary movement was deeply intertwined with colonialism ever since the 16th century (Bosch 1991:303) and therefore, from that point of view, the connection between globalisation and Christianity seems unmistakable. But when one goes back further, reading even the early history of Christianity through a globalisation lens, as my students and I did in our course, it seems clear that Christianity was a globalising religion from the beginning. This is particularly evident when one considers the cross-cultural missionary endeavours of the apostle Paul. According to Robert Wright (2009), Paul might be seen as acting within the context of the Roman Empire, which was an environment in many ways analogous to our contemporary globalising world. He was not just a preacher, but an 'entrepreneur', successfully extending his 'Jesus brand', by means of the most advanced information technology of his time, the written word in the form of 'the epistle' (Wright 2009:1). Furthermore, Paul associated with business minded people, such as Lydia (Ac 16) and Priscilla and Aquila (Ac 18), who helped him to extend and strengthen his network of churches, or to use Wright's globalisation language: 'Christian franchises' (Wright 2009:3). Many of Paul's associates were city-dwellers, 'cosmopolitan' and multicultural and likely to be tolerant of 'ethnic difference', even if the reasons for such tolerance might not be purely altruistic, but perhaps also relating to the mundane realities of commerce (Wright 2009:3). Of course, sceptics would argue that anything could be read into history and so one needs to be careful when conjecturing in this regard. Yet I am convinced that the seeds of globalisation were planted early on in the history of Christianity and I will supply more examples of this in what follows.

In the Marxist-materialist understanding of globalisation, where it is all about economics, the European missionaries that accompanied the Spanish and Portuguese Conquistadores to the West, and the ships of the East India Company to the South and the East, were either reactionaries or collaborating opportunists, seeking somehow to participate in and gain from a process over which they had no direct control. My reading of Christian cultural history, on the other hand, has more affinity with the perspectives originally touted around the turn of the previous century by Max Weber (cf. 1958) and Ernst Troeltsch (cf. 1992) and more recently applied to globalisation by Max Stackhouse (cf. 2010). Stackhouse describes the two different understandings of the role of Christianity in history as the 'sociopsychological' and 'cybernetic' theories of religion. The former, somewhat dominant theory relies exclusively on a hermeneutic of suspicion, whereas the latter opens the door for a hermeneutic of trust. Stackhouse (2010:415) favours the latter: 'The cybernetic theory holds that a rich and valid symbol set, rationally ordered and representing a comprehensive worldview, can and does shape cultural and 
social systems in decisive ways'. In other words, this nonreductionist view takes a wider perspective in which the market is not everything and religion has real power.

For the purpose of my argument, however, I will accept the dominant critical view of globalisation as the politically correct term for westernisation. Globalisation, as we know it today, is primarily an extension of the economical and cultural influences of the 'West' into the rest. This is not to suggest that it is in all cases an unwelcome extension. In some cultures it was an anticipated and sought after extension, although obviously not in all cases. Therefore, to identify globalisation with westernisation is not the same as summarily equating globalisation with Western 'imperialism.' The former point of view is based on the evidence of history, the latter leans more heavily on ideology.

Westernisation is also not simply Americanisation, as it so often is stereotyped. Although I do not wish to re-invent the proverbial wheel, a brief backward glimpse into one of the formative periods of Christianity might be in order here. Many of the roots of the so-called West and indeed of Western Christianity are to be found in the Roman Empire (cf. Brown 2003). It is in the expansionist culture of that earlier empire, and especially in the way it transformed Christianity, through which contemporary processes of globalisation become more understandable. For example, in the class on Christian Ethics and Globalisation, we spent a lot of time talking about the Roman emperor, Constantine, who was perhaps more responsible than any other single person in turning Christianity into a powerful resource for globalisation. Of course, at the time it was not known as globalisation; it was simply about extending the reach of Rome. Yet, if one considers Romanisation as a precursor of westernisation, one might justifiably project the term globalisation into the past.

In fact, Constantine achieved a synthesis between Christianity and Roman religion, but ironically this hybrid product was to become the Christian orthodoxy, which was an 'orthodoxy' even more basic than those issues that would later cause major divisions between the different streams of Christendom. Rituals inspired by Constantine included turning the Sunday into an official day of rest. Of course, Christians had celebrated Sunday as the day of the Resurrection since the 1st century, but Constantine's 'First Sunday Law', issued in $321 \mathrm{AD}$, ruled that 'the venerable Day of the Sun' should be a rest day for inhabitants of towns and cities, and particular mention is made of magistrates in the edict (Schaff 1902:380). This move was more than an egotistical power-play by the emperor. Constantine's pre-Christian devotion, which he never completely disavowed, belonged to the cult of the 'Unconquered Sun' and the emperor apparently felt it improper that legal disputes should be settled on the day of the Sun (Tomkins 2005:46; cf. Cramer 1996:4). However, the hybridity of Constantine's Christianity is perhaps no better illustrated than in the labarum, the cross-shaped symbol that Constantine adapted as military standard for the Roman Empire, a vision of which he allegedly had before the battle at Milvian Bridge (cf. Cameron \& Hall 1999:23-24). The battle precipitated a victory that was his stepping stone to power. In the popular version of Constantine's vision, the emperor simply saw the symbol of a cross in the sun, a version of which he subsequently ordered to be painted on the shields of his soldiers (Tomkins 2005:45). Although he eventually made Christianity the official religion of the empire, the legacy of the Unconquered Sun lingered.

At any rate, Christianity before and after Constantine looked decidedly different. In subsequent centuries crusaders and conquerors of far-flung lands would also go out to battle with crosses painted on their shields, perhaps nowhere better illustrated than in the red cross symbol, which the Knights Templar carried with them to the Holy Land, where their purposes were unfortunately not always equally holy (cf. Barber 1994). The visual symbol of the sun in Roman religion retreated over time as the cross proved more enduring, but perhaps the spirit of the Unconquered Sun lingered in the hybridised religious culture, which Christianity had become at the time of European colonial expansion. The influence of this religious culture spread far wider and deeper than the more isolated, yet explicitly religious examples of missionary orders and individuals. Yet, this seemingly obvious point had not been recognised all that often.

In an illuminating article on the religious foundations of globalisation, Ivan Strenski (2004:632) states that both social scientists and religious studies scholars have had virtually nothing to say on the religious factors that shaped globalisation. Presumably Strenski is unaware at the point of his writing of the contributions by Stackhouse and other theologians, or he simply abstains from taking seriously anything to do with theology. Nevertheless, Strenski independently arrives at the important connection between economic globalisation and certain developments in 'religious' (meaning Christian) history. He makes the important argument that certain theologies were not only:

critical in facilitating the rise of today's economic globalization but that their evangelical residues linger on today, finding their way eventually into the arguments of a kind of market 'theology' that supports limitless economic globalization.

(Strenski 2004:633)

In illustrating the point, Strenski refers to the 16th and 17th centuries and especially the writings produced by Spain's Salamanca School, such as Francisco de Vitoria's juridical thoughts on and justifications of the subjugation of the Americas (cf. eds. Pagden \& Lawrance 1992) and the writings of the Dutch Calvinist, Hugo Grotius. Although different in many respects, both these scholars, the one Catholic and the other Protestant, are shown to base their arguments in justifying warfare and the right to 'free passage' in foreign lands - a key concept in terms of globalisation - on their understandings of the 'law of nations', which, in turn, relies on 'natural law' for its early foundations (Strenski 2004:634, 643). Natural law, with its "'teleological" notion of nature' (Strenski 2004:636) was also more directly a handy aid for those Christian jurists in their propagation of early economic 
globalisation. 'Economic activity was one of those parts of creation where the "ends" of the divine purpose would be worked out' (Strenski 2004:636). Therefore, it would seem, the globalising economy of early modern Europe reaching its tentacles ever deeper into the New World could, from the above perspective, be justified as fulfilling the will of God. In fact, the process was simply understood as natural.

The conquering motif arguably remains in globalisation as westernisation. Nevertheless, contemporary globalisation is very different from the 'Violent Evangelism' (Rivera Pagán 1992) that characterised the conquest of the Americas. These days, violence tends to occur beneath the surface; when it is on the surface it is sophisticatedly presented to the worldwide audience as wars of 'liberation.'

\section{Christian ethical responses to globalisation \\ Christian Ethics and the problem of nearsightedness}

I have to agree with Strenski (2004:633) when he argues that it seems 'that liberationist critiques of economic globalization may be lacking in the means to achieve their own critical goals'. The reason, as Strenski points out, is that such ethical critiques fail to understand the 'evangelical zeal' with which proponents push their arguments, which themselves are based on 'quasi-religious' foundations (Strenski 2004:633). After two semesters of teaching a course on the subject, and having considered my students' reactions, my impression is that Christian ethical critiques of globalisation are greatly needed, but that much of what is available on the subject is somehow falling short of creating sufficient impact.

Consider, for example, the book by Rebecca Todd Peters (2004), In search of the good life, which I relied upon quite heavily as a textbook. Peters describes the situation along the lines of four 'theories' of globalisation. According to this scheme, the first two are the 'neoliberal' and 'social development' theories. These are dominant because both arise from 'neoclassical' economics. Both are also discounted as unsustainable and morally bankrupt, especially in the case of neoliberalism, which preferences economy over politics and other social concerns. Although development theory takes greater consideration of the role of governments, it is still shown to be exploitative and paternalistic, not to mention unviable because it is based on the false premise that the poor South could be uplifted to the level of the affluent North, without the latter having to lower its standards of living. As alternatives to these dominant globalisation models, Peters (2004) refers to 'Earthism' and 'Postcolonialism.' Although different in outlook and in terms of the demographics of their various proponents, both of these so-called 'resistance theories' are concerned with issues such as community, localisation and opposition to big business. In her final analysis, Peters argues that the way forward is for these two resistance models to combine their efforts and to seek greater integration with each other's concerns. This would strengthen opposition to the hegemony of the neoliberal and development theories (Peters 2004:189ff.). Therefore, Peters's position can be characterised broadly as one which is rooted in opposition to globalisation. Globalisation as we have it is understood as irredeemable. The whole project needs to be dismantled and the world must enter a new era, where humans are less selfish, less greedy, less exploitative and where the integrity of the planet and all life within it are respected.

Peters's perspective is in line with the 'liberationist critiques of economic globalization' mentioned by Strenski (see above). It is not hard to understand why she comes to the conclusion that she does, and I find her critique of the dominant models well justified. What I find lacking, however, is any attempt at making sense of globalisation historically, as a process that cannot be fully understood if one excludes the reality of it being deeply enmeshed in the history of Christianity. This is what Strenski partly describes and which is also understood by Stackhouse.

\section{Critical assessment of two ethicists' globalisation theories}

As both Stackhouse and Peters are Christian ethicists, it would perhaps be insightful to compare their respective evaluations of globalisation. I do not have the space here to do full justice to such an endeavour, but I would like to make an analogy using the term 'eschatology'. If ethical responses to globalisation were compared to theological understandings of the place of eschatology in Christian history, then I suggest Stackhouse would be working within the paradigm of a realising eschatology. For Stackhouse, globalisation has many problems. These problems are not, however, inherently rooted in globalisation. Rather, it seems, it is the de-Christianisation, or Christian withdrawal from processes which are or were essentially God-willed that is causing the problems. For example, Stackhouse (2010:422-423) mentions the apparent dearth of ethics in the curricula of US business schools, which seems to be partly to blame for the recent global financial crisis that started in the US stock exchange. The poor ethics of powerful individuals are, nonetheless, not to be lain at the door of globalisation. Stackhouse has much hope for the future of globalisation. He believes it is the responsibility of public theology to engage the process and contribute to turning the whole project towards something that reflects the core principles of its Christian foundation. Therefore it is like a realising eschatology. We have not got it right yet, but there are signs all around and these may point us in the right direction, the destination of which is within reach.

Peters's position on the other hand, eschatologically speaking, is comparable to premillennialism. ${ }^{1}$ For her, there

1.The term 'premillennialism' is used ironically in this comparison. Peters is no fundamentalist, yet her and other likeminded critics' sharply dichotomised ethical stances towards globalisation make this tongue-in-cheek comparison possible. Briefly, along with Bosch (1991:313-319), I understand premillennialism to refe to a particularly extreme version of North American evangelicalism arising out to a particularly extreme version of North American evangelicalism arising out of the 19th century, as represented by fire-and-brimstone preachers such as A.T. Pierson and Dwight L. Moody. The 'millennium', derived from Revelation 20, refers to the 1000 year reign of peace expected by premillennialists to be initiated upon Christ's Second Coming. Premillennialists tended towards a very negative appraisa of contemporary reality. 'Salvation meant being saved from the world' (Bosch 1991:318). The connection to Peters is that she seems to imply a view that 'the good life' would refer to life as saved from globalisation. 
is no 'middle ground' (Peters 2004:190) to be found between the dominant theories of globalisation, on the one hand, and the resistance theories, on the other. The reason for this is that the two perspectives are based on 'diametrically opposed' (Peters 2004:190) worldviews, the one taking economy as the starting point and the other the well-being of the earth community. For as long as this essential divide continues, for Peters, there could be no adequate compromise between the opposing sides. Therefore, there is really no alternative but for globalisation as we know it, indebted as it is to neoclassical economic theory, to be completely discarded, so that a new process can enfold as based on a combination or integration of the resistance theories. Peters does not specify how the end of the dominant paradigm of globalisation could come about, but certainly it would entail a wholesale abandonment of the 'capitalist agenda' (Peters 2004:190) that drives it. Because it is hard to see how the economic powers that be in this era of market states would willy-nilly give up their creed, the only alternative might be through overwhelming pressure from outside forces, such as a worldwide people's revolution bringing this monster to its knees, or an internal collapse caused by natural disasters, or the drying up of natural resources, any of which could conceivably happen to varying degrees of probability. However, what is clear is that such a momentous change in the way our world has become ordered would be nothing short of apocalyptic in scale. It is for this reason that I compare the view held by Peters to premillennialism. For the new golden age to be born there seems to be no alternative but for this present darkness to be completely and utterly abolished first. Once that has come to pass, the Garden of Eden could perhaps be recovered and communities could go back to low-impact subsistence farming. The focus could shift back from globalisation to localisation. No-one would be rich, but everyone would live within their means. Pollution would be something of the past and sustainability would be the guiding principle in human economical endeavours.

The vision of such a new golden age might seem good, but as with more traditional versions of 'premillennialist' theology, it also seems somewhat irresponsible when a vision is upheld or an agenda advocated without seriously discussing the procedure of getting from the darkness into the light. For example, surely would not millions of people have to die first for the remainder of the earth's population to live sustainably on the produce of subsistence farming? On an even more direct level when I was teaching the course on Christian Ethics and Globalisation, I could not help noticing the irony of our textbook disparaging the same globalisation, which has either directly or indirectly given rise to the very existence of the international studies programme into which all of the students in the class were enrolled, majoring in fields such as international business or international relations. A farewell to globalisation would mean a farewell to most of their career options. In all likelihood, it would mean the closure of the university where they are studying, the very existence of which should be ascribed to globalisation when viewed from a wider perspective. Keimyung University was founded by
Presbyterian missionaries from North America in the middle of the 20th century, right around the time when the presently dominant versions of economic globalisation also started gathering steam. Of course, theologians, particularly ethicists, can hardly afford the sin of sentimentalism. Therefore, some might argue that if universities and students' chosen career paths are unsustainable, if they somehow stand in the way of a more just world order, well let them be plunged asunder. And if the premillennial version of globalisation is true then that is precisely what will happen, whether one likes it or not.

Although it is easy to be a globalisation pessimist when considering the data, now is not the time for prophecies of doom. I feel the need to show glimpses of hope to my students, to somehow argue that this present world order is not hopelessly irredeemable, even if it remains deeply flawed. The realising eschatological vision of globalisation is helpful in this task, although the historian in me cautions that Stackhouse's version of globalisation tends towards the other extreme of being overly optimistic. Nevertheless, it is far preferable to the premillennialist version. Although it may have to be taken with a pinch of salt, the point is that it can be taken. At the very least it provides a link to and an opportunity for interdisciplinary dialogue between ethicists and theologians of mission. Looking at it from the latter perspective, I would like to propose a historical (re-) reading of the various processes of globalisation as a way of pursuing those necessary yet illusive visions of hope. When globalisation is considered diachronically, it soon becomes obvious that the moral high ground should not be trespassed upon by Christian ethicists. Christianity is too deeply entangled in the creation of globalisation for Christian ethicists to wash their hands of its processes. Rather than attempt to disavow this monster, Christian theologians should acknowledge and reclaim our partial ownership of it.

\section{The ambiguities of Christian history}

My preferred approach would be to take the ambiguities of church history as a starting point (cf. Thangaraj 2006). In particular, I would like to focus on existing stories about Christian redemption in spite of Christianity's complicity in exploitative patterns of globalisation. Let me begin this section by endorsing the perspective of Elizabeth Gerle (2000), who also refuses to interpret globalisation in terms of absolute binaries. For her, it is an ambivalent process appearing either negatively or positively depending on one's point of view. Gerle critiques the tendency of many Christians in 'late modernity' to understand their tradition in terms of a 'Paradise Lost' type of paradigm, in which they nostalgically long for an era of lesser complexity. As Gerle (2000) points out, there is a basic problem with such a view, because:

traditions are in themselves complex, with liberating as well as oppressing features. They ought to be interpreted as gardens to be nurtured and cared for rather than as mines where gold is to be found.

(Gerle 2000:164) 
It seems that this nurturing process would involve cooperation and dialogue with all people of good will. Therefore, she rejects communitarian or conservative theological approaches that set their versions of Christianity up and over against the 'secular world' (Gerle 2000:163, 170).

\section{Hybridity in the history of Christianity}

I agree with Gerle's (2000) vision of the collaborative, positive role that Christianity can play in globalisation not only because it makes sense in terms of the future, but because it is historically validated. In my reading of history, Christianity is characterised by hybridity all the way through. The idea of Christianity as a pure tradition is pure myth, as any historian of religion would know. The Christian tradition has always been involved in some sort of dialogue with the various other traditions and ideologies it encountered along the way (cf. Young 2006:1). I mentioned the example of the hybridisation achieved by Constantine, which might have partly contributed to the conquering motif in Christianity's contribution to globalisation, but there are also other examples of Christianity and Christian agents enabling other processes in globalisation which are much more benign processes of healing and integration, rather than conflict and radicalisation.

One of the best examples of early Christian hybridity involved the church in Antioch, as described in the New Testament book of Acts (see Ac 11 and, especially, Ac 15). Here a group of Greek-speaking Jewish followers of Jesus make the crucial decision to dispense with essential elements of their religious tradition for the purpose of inviting non-Jewish followers of Jesus into their community. In other words, the insiders deliberately contaminated their own tradition in order to practice what I call missiological hospitality. This act of thoughtful pluralisation is where Christianity becomes Christianity and where it ceases to be a branch of Judaism. Antioch is where the followers of Jesus were first called 'Christians', according to Acts 11:26. Therefore, Christianity was marked by hybridity from the start. This openness to plurality and an ethic of hospitality also happens to be one of the key features that would eventually enable Christianity to cross the multiple cultural boundaries that would transform it into the world religion that it is today. On this level, Christianity plays a role in globalisation, in which it not only extends its global reach but actually diversifies and pluralises itself along the way. This image stands in stark contrast to the more typical globalisation image of the 'McDonaldisation' effect, the ongoing formation of a superficial yet hegemonic culture, which is typically targeted by leftist critics (cf. Guttal 2007). Furthermore, at a time in world history when antiglobalisation lobbyists from the right keep hammering on the 'dangers' of immigration, this aspect of Christianity, that is, its hospitality in terms of plurality, should be ethically highlighted.

\section{Telling the good stories}

As with all theologians, Christian ethicists should learn from the bad stories in our collective history. But for the purpose of inspiring students and Christians at the grassroots with a hope-filled message, the good stories are the ones to tell. Indeed, there are countless stories of good Christian conduct available. There are the exceptional figures who serve as examples of how Christians should behave in an era of globalisation. In the 16th century there was Bartholomé de Las Casas and his unrelenting defence of the Native American population (cf. De Las Casas 1992), when his missionary peers were, for the most part, silent on the abuses taking place. There are also the more recent and contemporary examples of heroically selfless Christian conduct against systems of oppression and inequality, for which the names of Mother Theresa and Desmond Tutu spring to mind. And these stories should be told, not with the intention of whitewashing the negative and exploitative reality of Christianity's historical contributions to globalisation, but because these stories are the historical beacons where light could be shown to shine in the darkness. Just as with globalisation, which is partly its creation, Christianity itself has a terrible history. But Christianity's involvement in globalisation is also redeemable, if Christian Ethics could increasingly draw upon and learn from these good stories. The following story reported on by BBC News (Leyland 2009) is a great example of what could happen if some of the core principles of Christian tradition become actualised in history.

In 1839, British missionaries James Harris and John Williams landed on the South Pacific island of Erromango, with the intention of evangelising the native population. What the missionaries, to their detriment, did not know was that only a few days before, some European traders had killed a number of the islanders. Therefore, when the missionaries arrived they were themselves overpowered, killed and eaten by the islanders who had a history of occasional cannibalism. In all probability, this instance of cannibalism was a ritualised attempt at pacifying and securing the perceived power of the invading culture. Did it work? Perhaps not directly, but a different kind of power was indeed at work. Fast forward 170 years to 2009 and we find that the majority of the islanders, descendants of cannibals, are church-going Christians who feel remorse for the violence their ancestors had committed against the bearers of what had subsequently become their faith. They invite the descendents of Rev. Williams, still living in England, to visit their island for a ceremony of reconciliation. With descendents from both sides of the original conflict present, a ceremony is held in which the whole drama is ritually re-enacted. The ritual concludes with the descendents of the cannibals asking the forgiveness of the descendents of the missionary. In a subsequent interview, a descendent of John Williams recounts how his faith was restored by the islanders through this gesture in a way he could never have imagined before (Leyland 2009).

This story, although unique, touches upon themes familiar to many people around the world. Christianity, especially through the modern missionary movement, is deeply implicated in globalisation. A lot of that is very negative and violent. Worldviews have been destroyed and transformed. 
People from far-flung corners of the world have been subjected to the ways of the West. But, on the other hand, Christianity is perfectly suited as a religion that speaks to the experiences of those who have been thus subjected. For example, Gemma Tulud Cruz (2008) discusses the context of migration, which is often the experience of the most vulnerable in globalisation. Christianity has a special appeal and power in such situations, because, as Cruz (2008:368) points out, Christianity's 'master narratives' all seem to be told from the perspective of migration, exile, itinerancy, etcetera. If history is told from the perspective of pilgrims, whose Christian faith sustained them in the face of all manner of adversity, Christianity should be able to play an increasingly hopeful role in globalisation. Fortunately, in terms of Christian historiography, there seem to be indications of a growing recognition that church history, as most theologians have traditionally learned it, was too focused on big names and powerful figures and far too little on the often hopeful and faithful, yet little-mentioned lives of ordinary Christians (cf. Bass 2009).

\section{Conclusion}

Historical tales of ordinary Christians whose faith sustained them in tough situations, as well as the more recent narratives such as the one I recounted above, show that through the Gospel there is another kind of power at work, which could heal injustices in unexpected ways. Although it might be argued that the mouse-sized forgiveness asked for by the islanders of Erromango and granted by their British guests, actually serves to remind us that there is a veritable elephant of forgiveness that needs to go the other way. On a more global scale it is the West that needs the forgiveness of the Rest. This is what I suggest might be a worthy role for Christian Ethics in terms of globalisation, that is, pointing out both the historical and contemporary contexts in which forgiveness needs to happen. Therefore, I would tentatively like to suggest an increasingly interdisciplinary approach for Christian Ethics. An ethics that would engage seriously with other theological fields such as church history, missiology and practical theology might orient itself fluently in terms of storytelling, historical role model searching, and reenactment. This might mean a partial farewell to the idea of Christianity as a counter-cultural protest movement. As I have indicated, this is a role Christianity cannot play with any degree of legitimacy because of its hybridising tendencies and intercultural entanglements throughout history. It would be much more hopeful if more Christians could follow the example of those islander descendents, by focusing, instead, on the humbler process of a rediscovery of meaning and healing through ritual.

\section{References}

Barber, M., 1994, The new knighthood: A history of the Order of the Temple, Cambridge University Press, Cambridge.

Bass, D.B., 2009, A people's history of Christianity: The other side of the story, HarperCollins, New York, NY.

Bosch, D.J., 1991, Transforming mission: Paradigm shifts in Theology of Mission, Orbis Books, Maryknoll, NY.

Brown, L.R., 2005, Outgrowing the Earth: The food security challenge in an age of falling water tables and rising temperatures, W.W. Norton \& Company, New York, NY.

Brown, P., 2003, The rise of Western Christendom: Triumph and diversity, AD 2001000 , 2nd edn., Blackwell, Malden, MA.

Cameron, A. \& Hall S., 1999, Eusebius: Life of Constantine, Oxford University Press, New York, NY.

Chomat, P., 2004, Oil addiction: The world in peril, Universal Publishers, New York, NY.

Cramer, F.H., 1996, Astrology in Roman law and politics, Ares, Chicago, IL.

Cruz, G.T., 2008, 'Between identity and security: Theological implications of migration in the context of globalization', Theological Studies 69, 357-375.

De Las Casas, B., 1992, In defense of the Indians, transl. S. Poole, Northern Illinois University Press, DeKalb, IL.

Gerle, E., 2000, 'Contemporary globalization and its ethical challenges', The Ecumenical Review 52(2), 158-171. doi:10.1111/j.1758-6623.2000.tb00429.x

Guttal, S., 2007, 'Globalisation', Development in Practice 17(4-5), 523-531.

Hopkins, A.G. (ed.), 2003, Globalization in world history, W.W. Norton \& Company, New York, NY.

Lane, J.E., 2008, Globalization: The juggernaut of the 21st century, Ashgate, Burlington, VT.

Leyland, B., 2009, 'Island holds reconciliation over Cannibalism', BBC News, 07 December, viewed 25 September 2010, from http://news.bbc.co.uk/2/hi/uk news/england/hampshire/8398126.stm

McGourty, C., 2009, 'Global crisis “to strike by 2030”', BBC News, 19 March, viewed 30 December 2010, from http://news.bbc.co.uk/2/hi/uk_news/7951838.stm

Mish, F.C. (ed.), 2004, The Merriam-Webster Dictionary, Merriam Webster, Springfield, MA.

Oreskes, N., 2004, 'Beyond the ivory tower: The scientific consensus on climate change', Science 306(5702), 1686. doi:10.1126/science.1103618, PMid:15576594

Pagden, A. \& Lawrance, J. (eds.), 1992, Vitoria: Political writings, Cambridge texts in the history of political thought, Cambridge University Press, New York, NY.

Peters, R.T., 2004, In search of the good life: The ethics of globalization, Continuum, New York, NY.

Rivera Pagán, L.N., 1992, A violent evangelism: The political and religious conquest of the Americas, transl. M. Herrera, Westminster \& John Knox Press, Louisville, KY. Schaff, P., 1902, History of the Christian Church, vol. 3, 5th edn., Scribner, New York,
NY.

Stackhouse, M.L., 2010, 'Framing the global ethos', Theology Today 66, 415-429. doi:10.1177/004057361006600402

Standlea, D.M., 2006, Oil, globalization, and the war for the Arctic refuge, SUNY Press, Albany, NY.

Strenski, I., 2004, 'The religion in globalization', Journal of the American Academy of Religion 72(3), 631-652. doi:10.1093/jaarel/Ifh062

Thangaraj, T.M., 2006, 'Christianity and the religions in the new Christianity', Review and Expositor 103(Summer), 497-517.

Tomkins, S., 2005, A short history of Christianity, Eerdmans, Grand Rapids, MI.

Troeltsch, E., 1992, The social teachings of the Christian churches, 2 vols., transl. O. Wyon, Westminster John Knox Press, Louisville, KY.

Weber, M., 1958, The Protestant ethic and the spirit of capitalism, transl. T. Parson Charles, Scribner's Sons, New York, NY.

Wright, R., 2009, 'One world under God', Atlantic Magazine, 01-04 April, viewed 15 December 2010, from http://www.theatlantic.com/magazine/archive/2009/04/ one-world-under-god/7335/

Young, R.F., 2006, “'God of a Thousand Heads": The syncretism of mission and the mission of syncretism, with special reference to the Catholic "Pseudo-Vedas" of 18th-century South India", paper presented at the 19th European Conference on Modern South Asian Studies - ECMSAS, Leiden, The Netherlands, 27-30 June. 